\title{
Cholesterol and its association with muscle weakness in critical illness
}

\author{
Daniel A. Hofmaenner ${ }^{1 *} \mathbb{D}$, Anna Kleyman ${ }^{1}$ and Mervyn Singer ${ }^{1}$
}

\section{Dear Editor,}

With great interest we read and appreciated the recently published article by Goossens and colleagues [1]. They offer some important insights into the phenomenon of muscle weakness in critical illness and suggest a contributory role of low cholesterol and potential utility from exogenous administration of 3-hydroxybutyrate. It has long been recognized that low serum cholesterol is commonplace in sepsis and an important prognosticator of poor outcomes [2,3]. They reported that 3-hydroxybutyrate (3-HB) increased plasma cholesterol levels in septic mice with normalization of plasma mevalonate and increased expression of genes encoding cholesterol synthesis in muscle.

We would like to raise some points of interest that merit discussion. First, the authors measured serum cholesterol levels in patients on ICU admission and day 3, whereas muscle strength was assessed at day 8 . What was the rationale for the choice of these timepoints? Ideally, comparison of muscle strength should be made against contemporaneous cholesterol levels to reduce risks of confounding and to support causality arguments.

Second, did the authors consider measuring endogenous production of 3- $\mathrm{HB}$ and plasma levels in their septic animals? Endogenous hydroxybutyrate levels are altered in sepsis due to a shift towards fat metabolism

This comment refers to the article available online at https://doi.org/10.1186/ s13054-021-03688-1.

${ }^{*}$ Correspondence: d.hofmanner@ucl.ac.uk

${ }^{1}$ Bloomsbury Institute of Intensive Care Medicine, Division of Medicine,

University College London, London WC1E 6BT, UK and increased ketone body production [4]. Understanding of the pharmacokinetics/pharmacodynamics of exogenous 3-HB administration would aid interpretation of its impact.

Third, the authors present the fate of supplemented 3-HB as cholesterogenic or tricarboxylic acid cycle (TCA cycle) substrate (Figure 3). A complementary pathway worth considering is fatty acid synthesis which also relies upon acetyl-CoA as a basic substrate. Again, temporal measurement across the catabolic and recovery phases of sepsis would be informative.

Fourth, to our knowledge, the liver produces ketone bodies but cannot directly metabolize them due to a lack of ketoacyl-CoA transferase. The observed elevation in mevalonate within the liver after exogenous 3-HB administration may relate to indirect metabolic pathways, e.g. via fatty acids transported back to the liver.

\section{Authors' response}

Reply to letter by Hofmaenner D.

\section{Lies Langouche ${ }^{2}$ and Greet Van den Berghe ${ }^{2}$}

${ }^{2}$ Clinical Division and Laboratory of Intensive Care Medicine, Department of Cellular and Molecular Medicine, KU Leuven, 3000 Leuven, Belgium.

We thank Hofmaenner D. et al. for the interest in our work on the role of cholesterol in ICU acquired weakness and the impact thereof on exogenous 3-hydroxybutyrate (3HB) and for raising several interesting points [1].

The first point addressed the difference in timing between measurement of serum cholesterol and of muscle strength in the human study (EPaNIC RCT). In this study, the impact of omitting parenteral nutrition for one original author(s) and the source, provide a link to the Creative Commons licence, and indicate if changes were made. The images or other third party material in this article are included in the article's Creative Commons licence, unless indicated otherwise in a credit line to the material. If material is not included in the article's Creative Commons licence and your intended use is not permitted by statutory regulation or exceeds the permitted use, you will need to obtain permission directly from the copyright holder. To view a copy of this licence, visit http://creativecommons.org/licenses/by/4.0/. The Creative Commons Public Domain Dedication waiver (http://creativeco mmons.org/publicdomain/zero/1.0/) applies to the data made available in this article, unless otherwise stated in a credit line to the data. 
week in ICU on ICU acquired weakness was assessed in a matched subgroup of 600 patients on post-randomization day 8 [5]. Muscle strength assessment was performed in ICU for long-stay patients, and on the regular ward for short-stayers. Blood was only sampled during ICU stay, and thus no later samples were available for short-stayers. For the current analysis of a potential association between plasma cholesterol and ICU acquired weakness, we therefore quantified plasma cholesterol in all patients on one timepoint, day 3 in ICU, which preceded the muscle strength assessment, as selection bias would otherwise occur at a later time point.

Second, the authors asked whether data on endogenous production of $3 \mathrm{HB}$ and plasma concentrations were available for the septic mice. Indeed, as mentioned by Hofmaenner D. et al., endogenous production of $3 \mathrm{HB}$ is increased in the acute phase of critical illness, but this is abolished as soon as parenteral nutrition is initiated, as we have previously shown both in the septic mouse model [6], and in human patients [7, 8]. We agree that further insight in the pharmacokinetics/pharmacodynamics of exogenous $3 \mathrm{HB}$ administration would be informative when considering its further investigation in human ICU patients.

The third and fourth points addressed the metabolic fate of the exogenous $3 \mathrm{HB}$ and whether use as substrate for fatty acid synthesis could be involved. Indeed, $3 \mathrm{HB}$ can in theory be converted into fatty acids. In the mouse model, 3HB supplementation has previously shown not to alter plasma fatty acid concentrations or triglyceride content in muscle or liver [6], whereas it was found to increase plasma triglyceride concentrations [6]. Indirectly, it is also possible that conversion of $3 \mathrm{HB}$ to fatty acids or mevalonate in non-hepatic tissues may have occurred which could then be further metabolized in the liver.

We totally agree with Hofmaenner D. et al. that more research is needed to better understand the role of cholesterol in ICU acquired weakness and to assess the clinical potential of $3 \mathrm{HB}$ supplementation in human ICU patients.

\section{Acknowledgements}

None.
Authors' contributions

DAH drafted the first version of the manuscript. DAH, AK and MS have edited and proofread the final manuscript version.

Funding

None.

Availability of data and material

Not applicable.

\section{Declarations}

Ethics approval and consent to participate

Not applicable.

Consent for publication

Not applicable.

\section{Competing interests}

The authors declare that they have no competing interests.

Received: 28 July 2021 Accepted: 29 July 2021

Published online: 17 August 2021

\section{References}

1. Goossens C, Weckx R, Derde S, Vander Perre S, Derese I, van Veldhoven PP, et al. Altered cholesterol homeostasis in critical illness-induced muscle weakness: effect of exogenous 3-hydroxybutyrate. Crit Care. 2021;25(1):252

2. Chien JY, Jerng JS, Yu CJ, Yang PC. Low serum level of high-density lipoprotein cholesterol is a poor prognostic factor for severe sepsis. Crit Care Med. 2005;33:1688-93.

3. van Leeuwen HJ, Heezius EC, Dallinga GM, van Strijp JA, Verhoef J, van Kessel KP. Lipoprotein metabolism in patients with severe sepsis. Crit Care Med. 2003:31:1359-66.

4. Wasyluk W, Zwolak A. Metabolic Alterations in Sepsis. J Clin Med. 2021:10(11):2412.

5. Casaer MP, Mesotten D, Hermans G, Wouters PJ, Schetz M, Meyfroidt G, et al. Early versus late parenteral nutrition in critically ill adults. N Engl J Med. 2011:365(6):506.

6. Goossens $C$, Weckx R, Derde S, Dufour T, Vander Perre S, Pauwels $L$, et al. Adipose tissue protects against sepsis-induced muscle weakness in mice: from lipolysis to ketones. Crit Care. 2019;23(1):236.

7. De Bruyn A, Gunst J, Goossens C, Vander Perre S, Guerra GG, Verbruggen $\mathrm{S}$, et al. Effect of withholding early parenteral nutrition in PICU on ketogenesis as potential mediator of its outcome benefit. Crit Care. 2020;24(1):536.

8. De Bruyn A, Langouche L, Vander Perre S, Gunst J, Van den Berghe G. Impact of withholding early parenteral nutrition in adult critically ill patients on ketogenesis in relation to outcome. Crit Care. 2021;25(1):102.

\section{Publisher's Note}

Springer Nature remains neutral with regard to jurisdictional claims in published maps and institutional affiliations. 